PAEDAGOGiA ChRISTIANA

I /23(2009) - ISSN 1505-6872

Dariusz Buksik*

Warszawa

\title{
Poziom rozwoju życia religijnego młodzieży z ośrodka wychowawczego
}

Poziom rozwoju życia religijnego u każdego człowieka wyraża się inaczej. W rozwoju tym nie ma czegoś takiego, co jednoznacznie można określić jako pewnego rodzaju stopień dojrzałości religijnej. Rozwój religijny jest procesem długotrwałym i stopniowym. Jednocześnie jest to proces trudny, bo warunkowany wieloma czynnikami czy to natury zewnętrznej, jak wychowanie rodzinne, czy też natury wewnętrznej, jak osobiste doświadczenia. W rozwoju religijnym ważne miejsce ma moment, w którym człowiek dojrzewa oraz usamodzielnia się poprzez kształtowanie osobistego światopoglądu.

$\mathrm{W}$ procesie wychowania i profilaktyce, czy też pewnego rodzaju resocjalizacji wielu autorów zwraca uwagę, że uzasadnione jest odwoływanie się do prawidłowo ukształtowanej religijności. Wcześniejsze doświadczenia religijne mogą bowiem być początkiem procesu przemiany świadomości osób podlegających resocjalizacji. Odniesienie się do religii i wskazywanie na proces rozwoju religijnego staje się propozycją wzmocnienia działań na rzecz socjalizacji. W pewnym stopniu posługi religijne w ośrodkach wychowawczych czy instytucjach resocjalizacyjnych stanowią istotną formę działalności resocjalizacyjnej w stosunku do osób, których system wartości, normy moralne, zachowania społeczne zostały w wadliwy sposób zinternalizowane. Uważa się dzisiaj, że możliwe jest odwoływanie się do wartości religijnych w procesie wychowania i resocjalizacji, mimo że obecnie zauważa się mniejszą wrażliwość na wartości moralne, religijne, duchowe $\mathrm{w}$ procesie wychowania ${ }^{1}$.

${ }^{*}$ Ks. dr Dariusz Buksik SDB, adiunkt w Instytucie Psychologii na Wydziale Filozofii Chrześcijańskiej Uniwersytetu Kardynała Stefana Wyszyńskiego w Warszawie.

${ }^{1} \mathrm{~J}$. Malec, Postugi religijne $w$ zakładach karnych, „Przegląd Penitencjarny i Kryminologiczny” 14-15 (1989), s. 21-24; K. Ostrowska, Wokót rozwoju osobowości i systemu wartości, Warszawa 1998, s. 156-161; D. J. Pol, Postawy religijne w resocjalizacji skazanych, „Seminare. Poszukiwania Naukowo-Pastorlane" 18 (2002), s. 488-497. 
Głównym założeniem niniejszego opracowania jest ukazanie i zbadanie poziomu życia religijnego młodego człowieka poddanego procesowi wychowania i resocjalizacji w ośrodku wychowawczym oraz wskazanie na tej podstawie wniosków wychowawczych pozwalających przez sferę religijnych odniesień kształtować dojrzałą osobowość.

\section{Znaczenie rozwoju religijnego $\mathrm{w}$ procesie wychowawczym, profilaktyce oraz resocjalizacji młodzieży}

Pojęcie „religia” może być rozpatrywane zarówno w znaczeniu przedmiotowym, jak i podmiotowym ${ }^{2}$. Religia rozumiana przedmiotowo oznacza zespół prawd, norm postępowania, czynności obrzędowych oraz instytucji, które wyjaśniają i regulują stosunek człowieka jako jednostki lub członka grupy społecznej do Boga ${ }^{3}$. Natomiast w znaczeniu podmiotowym to ,przejawiająca się w myśleniu, odczuwaniu, pragnieniu i postępowaniu wiara w istnienie nadprzyrodzonych, osobowych lub bezosobowych mocy, od których człowiek czuje się zależny, które stara się sobie pozyskać albo, ku którym usiłuje się wznieść"4. Charakterystyczną postawę wobec religijności przyjmuje w swoich poglądach C. G. Jung. Przedmiotem jego zainteresowań były religijne przeżycia jako zjawiska powszechne i zawsze istniejące. Uważał, że idea religijna ,jest psychologicznie prawdziwa o tyle, o ile istnieje”. Co więcej, jest ona „szczególną postawą ludzkiego umysłu". Rozważając problem religijności, Jung wyraźnie stwierdza, że „przejawy funkcji religijnej w człowieku są tak nadzwyczajne i niezwykłe, a ich właściwości są tak odmienne od innych funkcji ludzkich, że nie ma możliwości sprowadzenia religii do jakiejś innej ludzkiej działalności”'. Inne ujęcie prezentuje E. Fromm, który ujmuje religię jako jedną z prób rozwiązywania egzystencjalnego problemu człowieka. Interesuje się on religią głównie w aspekcie jej funkcjonowania w konkretnych przeżyciach jednostek oraz z punktu widzenia roli, jaką pełni w procesie kształtowania się osobowości. E. Fromm pisze, że „nie ma człowieka bez potrzeby religijnej, potrzeby posiadania układu orientacji i przedmiotu czci”". Religijność uważa za konieczną cechę człowieka. Dla E. Fromma religia ma charakter terapeutyczny. Pojęcie religijności wprowadza również G. W. Allport, który ukazuje je w terminach sentymentu religijnego, czy też poczucia religijnego. Pisze on między innymi, że ,nie każda dojrzała jeds. $20-47$.

${ }^{2}$ W. Prężyna, Funkcja postawy religijnej w osobowości człowieka, Lublin 1981,

${ }^{3}$ J. Pastuszka, Osobowość a religijność człowieka. Analiza psychologiczna, „Roczniki Filozoficzne" 12 (1964), z. 4, s. 5-16.

${ }^{4}$ H. Glasenapp, Religie niechrześcijańskie, Warszawa 1966, s. 87.

${ }^{5}$ C. G. Jung, Psychologia a religia, Warszawa 1995, s. 15, 81-83, 225.

${ }^{6}$ E. Fromm, Szkice z psychologii religii, Warszawa 1980, s. 137. 
nostka wytwarza w sobie poczucie religijne. Jeżeli tego nie czyni, to dlatego, że posiada jakąś inną zadowalającą filozofię życia, jakąś formę syntez, może o charakterze etycznym lub filozoficznym"'.

$\mathrm{Na}$ religijność człowieka zwraca uwagę również V. E. Frankl, który akcentuje w sposób szczególny znaczenie zdolności człowieka do transcendencji własnego ,ja”. Zdaniem Frankla, w sytuacji cierpienia, poczucia winy i śmierci człowiek zdolny jest otworzyć się na jakiś nad-sens. Stąd też „,nauka o istocie ludzkiej musi być otwarta, otwarta na świat i zaświaty, musi zachować drzwi otwarte ku transcendencji. Przez te otwarte drzwi pada cień absolutu". Dalej twierdzi, że ,zarówno analiza egzystencjalna, jak i logoterapia mają nie tylko prawo, ale i obowiązek, zajmować się takimi problemami, albowiem przy stosowaniu psychoterapii obydwie spotykają się z problematyką religijności"».

We współczesnej psychologii religii wyróżnia się religijność zewnętrzną i wewnętrzną oraz religijność personalną i apersonalną. Religijność zewnętrzna służy zdobyciu poczucia bezpieczeństwa, pozycji społecznej. Nie uwzględnia się w niej całości prawd religijnych, lecz wybiera to, co zgadza się z własnym interesem jednostki. Religijność ta jest mało zróżnicowana, schematyczna i ma cechy ekskluzywizmu, bo faworyzuje tzw. prowincjonalizm i szufladkowanie. Człowiek o religijności zewnętrznej widzi szczególnie społeczne jej funkcje (np. to, że daje ona poczucie związku z grupą społeczną), praktykuje okolicznościowo i pod wpływem drugorzędnych motywów. Natomiast religijność wewnętrzna przenika całe życie człowieka, łączy potrzeby i wartości jednostki z normami społecznymi. Jest bardziej refleksyjna i zróżnicowana, osobowa i uniwersalna, nastawiona na braterstwo, miłość bliźniego, życzliwość. Wartość religijna dla jednostek o religijności wewnętrznej jest absolutnie najwyższa. Żyjąc taką religijnością, poszukuje się pokornie głębszych wartości i chętnie także uczestniczy we wspólnocie. Religijność personalna oparta jest na relacji partnerskiej „Ja-Człowiek” z ,Ty-Bóg”. Człowiek jest wolny, twórczy, otwarty, spontaniczny, mający poczucie własnej godności, jest odpowiedzialny i ma zintegrowany system wartości. W religijności apersonalnej człowiek traktuje Boga jako zaspokojenie własnych egoistycznych potrzeb. Człowiek o takiej religijności czuje się przymuszony do wiary, nie ma poczucia wolności, nie jest twórczy i traktuje praktyki religijne biernie?

Zaprezentowane koncepcje i poglądy psychologiczne nie są wyczerpujące, jednak pozwalają wyciągnąć wniosek, że w całym procesie wychowawczym czy też profilaktyce osób młodocianych należy uwzględniać poziom ich życia religij-

${ }^{7}$ G. W. Allport, Osobowość i religia, Warszawa 1988, s. 140.

${ }^{8}$ V. E. Frankl, Homo patiens, Warszawa 1984, s. 93, 112.

9 J. Pastuszka, Religijność zewnętrzna i wewnętrzna, „Homo Dei” 2 (1958), s. 195-199; Z. Uchnas, Psychologiczne aspekty motywacji religijnego zachowania, „Częstochowskie Studia Teologiczne" 5 (1977), s. 328-331; R. Jaworski, Psychologiczne korelaty religijności personalnej, Lublin 1989, s. 20-67. 
nego, gdyż jest on nie tylko ważny, ale istotnie może przyczyniać się do ukształtowania dojrzałej osobowości. W całym procesie integralnego wychowania młodego człowieka należy coraz bardziej wskazywać na wszystkie jego wymiary, tj. wymiar biologiczny, psychiczny, społeczny i duchowy. Człowiek rozwija się we wszystkich tych płaszczyznach. Czasami proces tego rozwoju jest zrównoważony, czasami jednak taki nie jest, a wręcz przeciwnie, przybiera różne postaci dewiacji. Wielu autorów zwraca uwagę, że pewnego rodzaju poziom życia religijnego, postawy, wybory i zaangażowanie religijne, aktywność w płaszczyźnie życia religijnego tworzą dobrą sferę ochronną przed dewiacją, przestępczością, a także innymi zaburzeniami społecznej sfery osobowości ${ }^{10}$.

\section{Poczucie winy, wrażliwość sumienia oraz postawy religijne jako elementy składowe wyznaczające poziom życia religijnego}

W niniejszym opracowaniu wskaźniki poziomu życia religijnego młodzieży ograniczono do kilku wybranych. Są nimi poczucie winy, postawy religijne i wrażliwość sumienia. Elementy te potraktowano jako pewnego rodzaju wyznaczniki poziomu życia religijnego osób młodych przebywających w ośrodku wychowawczym, a tym samym objętych procesem wychowawczym i resocjalizacyjnym.

\subsection{Poczucie winy}

Słownik Sillamy’ego podaje następujące określenie poczucia winy: „Stan osoby, która popełniła występek. Obok poczucia winy za rzeczywiste, obiektywne przekroczenie jakiejś normy, u wielu jednostek spotkać można mniej lub bardziej wyraźnie poczucie odpowiedzialności i lęk, wywołane winami urojonymi" ${ }^{11}$. Poczucie winy najczęściej rozumiane jest jako zespół specyficznych reakcji obejmujących głównie wstyd, żal, złość na siebie, niepokój, negatywną samoocenę powstałą na skutek zachowań niezgodnych z regułami etycznymi, jakie jednostka uznaje. Zachowanie niezgodne $\mathrm{z}$ tymi regułami jest zazwyczaj rozumiane jako uleganie jakimś własnym popędom, które moralność jednostki nakazuje tłumić. Istnieją kontrowersje na temat tego, czy poczucie winy polega głównie na przeżywaniu reakcji lęku, gniewu na siebie i niskiej samooceny czy raczej żalu połączonego z niską samooceną ${ }^{12}$. Poszczególni autorzy zajmujący się problematyką poczucia winy w odmienny sposób ujmują ten złożony proces.

${ }^{10} \mathrm{~K}$. Ostrowska, dz. cyt., s. 156-161.

${ }^{11}$ N. Sillamy, Stownik psychologii, Katowice 1995, s. 211.

${ }_{12}$ A. Grochowska, Wybrane metody badania poczucia winy, poczucia kontroli, poczucia sensu życia, sympatii, empatii, w: S. Siek (red.), Wybrane metody badania osobowości, Warszawa 1993, s. 423-464. 
Według Znamierowskiego ${ }^{13}$, w skład poczucia winy wchodzi żal, współczucie dla pokrzywdzonego, gniew na samego siebie, wstyd oraz ujemna ocena siebie, która jest rdzeniem poczucia winy. Mc Kenzie ${ }^{14}$ określa poczucie winy jako lęk przed konsekwencjami takiego zachowania, które pozwala na swobodny upust popędów. Wantuła ${ }^{15}$ za podstawowe źródło poczucia winy uważa konflikt pomiędzy miłością i agresją. Natomiast May ${ }^{16} \mathrm{w}$ duchu psychologii egzystencjalnej utrzymywał, że jest się winnym, a nie tylko posiada się poczucie winy, co powinno, jego zdaniem, chronić przed subiektywnością własnych odczuć. Właściwe poczucie winy wiąże on z pojęciem ontologicznego poczucia winy. Wyróżnia także poczucie winy wynikające z niemożności pełnego zrozumienia i zaspokojenia potrzeb oraz to, które jest skutkiem separacji od świata przyrody. Jeżeli któraś z tych form poczucia winy jest nieakceptowana, może przerodzić się w neurotyczne poczucie winy.

Zjawisko poczucia winy ma duży wpływ na funkcjonowanie osobowości. Stąd też Dąbrowski ${ }^{17}$ dostrzega destrukcyjną dla osobowości rolę poczucia winy, ale ze względu na określony ideał osobowości wartościuje tę destrukcję w sposób dodatni. Posługując się pojęciem dezintegracji pozytywnej, podaje on, że poczucie winy ma moc dezintegrującą i ocenia jego funkcję pozytywnie. Uważa przy tym, że tworzy ono twórcze napięcie, stanowiące podstawę pracy samowychowawczej. W przeżywaniu poczucia winy Kuczkowski ${ }^{18}$ wyróżnia cztery komponenty: element emocjonalny, komponent treściowy, czynnik czasu oraz kontrolę woli. W psychologii podkreśla się również, m.in. Poznaniak ${ }^{19}$, że poczucie winy może być mniej lub bardziej racjonalne lub nieracjonalne. $\mathrm{Z}$ racjonalnym poczuciem winy będziemy mieć do czynienia tam, gdzie jest ono reakcją (lub względnie stałą dyspozycją do takiego reagowania) na rzeczywiste przekroczenie standardów moralnych. Natomiast nieracjonalne poczucie winy nie spełnia tych warunków, a nawet dostarcza samemu człowiekowi oraz otoczeniu licznych cierpień. Poczucie winy odgrywa istotną rolę w regulacji społeczno-moralnego zachowania się człowieka i wyznacza jakościowo odmienne wzorce postępowania. Poczucie winy na ogół zabezpiecza jednostkę przed podejmowaniem czynów nieetycznych, nawet wtedy, gdy nie ma kontroli społecznej. Oznacza to, że poczucie winy w pewnym sensie uniezależnia działanie jednostki od wpływu społecznego.

${ }^{13}$ Cz. Znamierowski, Oceny i normy, Warszawa 1957, s. 15-19.

${ }_{14}^{14}$ J. G. Mc Kenzie, Guilt. Its Meaning and Significance, London 1962, s. 6-12.

${ }^{15}$ H. Wantuła, Problemy poczucia winy, „Etyka” 7 (1970), s. 159-181.

${ }^{16}$ R. May, Psychologia i dylemat ludzki, Warszawa 1989, s. 23-34.

${ }^{17}$ K. Dąbrowski, Dezintegracja pozytywna, Warszawa 1979, s. 16-70; tenże, Trud istnienia, Warszawa 1986, s. 45-51.

${ }^{18}$ S. Kuczkowski, Poczucie winy w literaturze psychologicznej, „Collectanea Theologica” 44 (1974), nr 1, s. 65-75; tenże, Struktura i dynamika poczucia winy, „Collectanea Theologica” 44 (1974), nr 3, s. 41-52.

${ }^{19}$ W. Poznaniak, Zaburzenia w uspołecznieniu u przestępców. Analiza niektórych mechanizmów psychologicznych, Poznań 1982, s. 60-134. 


\subsection{Postawa religijna}

Postawa jest to stan gotowości do czegoś, do jakiegoś czynu lub zachowania. Podstawową cechą postawy jest ustosunkowanie się podmiotu do przedmiotu. Formami tego stosunku są: przekonania, stosunek emocjonalny oraz reakcja uzewnętrzniona. Jest to zespół trzech komponentów: intelektualnego, emocjonalnego i behawioralnego ${ }^{20}$.

Jak pisze Prężyna, „przez postawę religijną rozumie się postawę, której przedmiot ma charakter religijny (ze względu na swoją treść), np. postawa wobec Boga, Kościoła jako instytucji religijnej itd. Przedmiotem postawy religijnej [...] jest Bóg, a ściślej mówiąc - cała rzeczywistość oznaczona pojęciem nadprzyrodzoności” ${ }^{21}$. W innym miejscu napisze: „Przez postawę religijną [...] rozumie się względnie trwałe ustosunkowanie się (intelektualne, emocjonalne i behawioralne) jednostki wobec Boga i nadprzyrodzoności”22. Ważnym wymiarem postawy jest psychologiczna centralność jej przedmiotu. „Przez centralność przedmiotu postawy rozumie się wymiar wskazujący na stopień psychologicznego (poznawczego, emocjonalno-motywacyjnego i behawioralnego) zaangażowania podmiotu przedmiotem postawy. Przedmiot ze względu na swoją treść może być bardziej lub mniej znaczący, ważny dla poszczególnych osób, może być w różnym stopniu angażujący (może wywoływać zainteresowanie, koncentrować sferę emocjonalną, motywować do określonych zachowań); mówiąc inaczej [...] może być mniej lub bardziej psychologicznie odległy (lub bliski)". Podstawowy mechanizm powiązania podmiotu z centralnością można wyjaśnić poprzez odniesienie przedmiotu do układu właściwych potrzeb danego podmiotu ${ }^{23}$.

Religijność, czyli religię indywidualnie przeżywaną przez podmiot, Chlewiński ${ }^{24}$ charakteryzuje za pomocą takich wymiarów, jak: centralność, głębokość, autentyczność oraz dojrzałość. W centralności dostrzega wymiar, który wskazuje na ważność i doniosłość, jaką posiada dany przedmiot dla jednostki. Jeśli przedmiot postawy religijnej znajduje się w centralnym miejscu jako wartość pierwszorzędna, to pozostałe wartości są jej podporządkowane. Przedmiot postawy może być w różnym stopniu przez daną jednostkę przemyślany, a także przeżyty, jako wartość o silnej mocy zobowiązującej. Jeśli występuje zgodność postępowania $\mathrm{z}$ wymaganiami, które implikują wartości religijne, nawet w sytuacjach

${ }^{20}$ M. Gołaszewska, Z badań nad funkcjami postaw, w: Z. Żarnecka (red.), Szkice filozoficzne Romanowi Ingardenowi w darze, Kraków 1964, s. 291-310; T. Mądrzycki, Psychologiczne prawidlowości ksztaltowania się postaw, Warszawa 1977, s. 48-54; W. Prężyna, Funkcja, s. 23-34.

${ }^{21}$ Tenże, Skala postaw religijnych, „Roczniki Filozoficzne” 16 (1968), z. 4, s. 77.

${ }^{22}$ Tenże, Potrzeby jako korelaty postawy religijnej, „Roczniki Filozoficzne” 24 (1976), z. 4, s. $5-28$.

${ }^{23}$ Tamże, s. 5-7.

${ }^{24}$ Z. Chlewiński, Wprowadzenie do psychologii religii, w: tenże (red.), Psychologia religii, Lublin 1982, s. 11-59. 
trudnych, to mówimy o autentycznej postawie religijnej. Należy podkreślić, że jeśli religijność jest centralną wartością, głęboko przeżywaną i autentyczną, to wówczas stanowi szczególne ukierunkowanie jednostki. Jeśli zaś wartości religijne będą zajmowały peryferyjne miejsce wobec innych wartości, to całość życia jednostki będzie poza treścią, jaką przedmiot religijny prezentuje. Aby religia pełniła funkcję integrującą osobowość, potrzeba, aby jej przeżywanie podmiotowe jak i osobowość charakteryzowały się dojrzałością. Ponadto należy mówić jeszcze za G. W. Allportem ${ }^{25}$ o niedojrzałej i dojrzałej postawie religijnej. Dojrzałą postawę religijną charakteryzuje: zróżnicowana, otwarta religijność oraz dynamiczność. Inspiruje ona konsekwentną moralność, jest zracjonalizowana i zintegrowana oraz posiada charakter poszukujący.

Należy również zaznaczyć, że relacja podmiotu (człowieka) do przedmiotu postawy (Boga) określana jest mianem przeżycia religijnego. Jest to podmiotowy aspekt religii. Przeżycie to dokonuje się na pewnej bazie intelektualno-poznawczej człowieka ${ }^{26}$. Natomiast o religijnym charakterze postawy decyduje religijność jej przedmiotu, czyli ta postawa będzie religijna, której przedmiot ze względu na treść będzie przynależał do religii w znaczeniu przedmiotowym ${ }^{27}$. Natomiast według Bazylaka ${ }^{28}$, trzy kryteria odróżniają postawę religijną od innych postaw. Są to: kryterium treści - ta postawa jest religijna, której przedmiot ma religijną treść; kryterium świadomości - ta postawa jest religijna, którą jednostka w świadomości swojej określa jako religijną oraz kryterium znaku i symboli - tym, co należy uznać za religijny znak-symbol decyduje środowisko kulturowe.

\subsection{Wrażliwość sumienia}

Można przyjąć założenie, że w psychologii sumienie traktowane jest jako świadomy element wewnętrznej (psychiczno-duchowej) rzeczywistości człowieka. Rozstrzyga o tym, co dobre, a co złe. Sumienie to z jednej strony zbiór postaw, według których jednostka ocenia własne postępowanie w świetle uwewnętrznionych norm moralnych, wartości i zasad, z drugiej zaś to system kontrolny sygnalizujący, czy popełnienie danego czynu jest właściwe czy nie. Sumienie jako system kontrolujący, który odnosi się zarówno do samego podmiotu, jak i do relacji tego podmiotu wobec innych, wobec otoczenia i wobec wartości ogólnie przyjętych w społeczeństwie. Są to elementy tworzenia się sumienia, choć z całą pewnością nie jedyne. Człowiek, jako istota rozumna, nieustannie ocenia swoje postępowa-

${ }^{25}$ G. W. Allport, dz. cyt., s. 15-18.

${ }^{26}$ J. Bielecki, Wybrane metody badania postaw wartościujacych i religijnych, w: S. Siek (red.), dz. cyt., s. 358-390.

${ }^{27}$ W. Prężyna, Zasadnicze źródła postaw, „Roczniki Filozoficzne” 21 (1973), z. 4, s. $121-$ -130 .

${ }^{28}$ J. Bazylak, Postawy religijne i ich zmiany, „Studia z Psychologii” 1 (1983), s. 7-25. 
nie i zachowanie w aspekcie dobra lub zła, a tym samym nieustannie zmierza do samourzeczywistnienia własnej egzystencji. W życiu jednostki, a także w funkcjonowaniu społeczeństwa, czy też dojrzałym rozwoju poziomu życia religijnego niezwykle ważne jest prawidłowo ukształtowane, wrażliwe sumienie.

W strukturze osobowości, jak twierdził Allport ${ }^{29}$, znajduje się sumienie, które jest najważniejszym czynnikiem rozwoju osobowości. Sumienie jest tym, co kontroluje doraźne impulsy i mechanizmy adaptacyjne pod kątem odległych zamierzeń i pod względem ich zgodności z obrazem własnej osoby. Sumienie jest intuicyjnym poczuciem dobra, na co wskazuje Szuman ${ }^{30}$, oraz świadomością etyczną zrodzoną nie z zewnętrznego nakazu, lecz z samej istoty człowieczeństwa. Z psychologicznego punktu widzenia sumienie jest samoczynnym, dobrze rozeznającym zmysłem i sądem trafnie oceniającym sprawy etyczne. Sumienie wspiera w człowieku prawe, szlachetne, twórcze człowieczeństwo, tak jak instynkt dba o twórczą zdolność życia w organizmie. Sumienie ma zdolność rozstrzygania nie tyle tego, czy coś jest przyjemne lub przykre, ile tego, czy coś jest dobre, czy złe. Niemniej, sumienie ludzkie nie mogłoby się rozwijać i dojrzewać bez pomocy rozumu, nie mogłoby też bez niego zdobyć dostatecznej pewności sądu w sytuacjach szczególnie zawikłanych i trudnych. Toteż sumienie przywołuje rozum do pomocy, gdy jego bezpośrednie rozeznanie jest niepewne i chwiejne. Rozum upewnia i popiera sumienie, ale nie może go zastapić. Może tylko działać w porozumieniu $\mathrm{z}$ nim $\mathrm{i}$ jakby w jego imieniu. W ostatecznej fazie rozwoju moralnego sumienie wciąż jeszcze czuwa nad tym, aby rozum się nie pomylił i naprawia jego błędy. Dzięki sumieniu człowiek czuje się osobą odpowiedzialną za swoje myśli i czyny, a dzięki poczuciu odpowiedzialności ma poczucie wolności i godności ludzkiej. Tak więc sumienie to zgodność z obrazem własnej osoby, to kontrolowanie tego, czy człowiek postępuje zgodnie ze standardami ludzkiej egzystencji, czy dąży do budowania dobra w swoim życiu. Standardy mogą być różne i może ich być wiele. Mogą nimi być godność, równość, miłość, sprawiedliwość, wolność, dążenie do powodzenia i uznania, dążenie do szczęścia, czy też pragnienie wzniesienia się ponad siebie. Sumienie kontroluje te lub jeszcze inne jakości ludzkiego życia, które mogą płynąć zarówno od samego człowieka, jak i z zewnątrz. Sumienie kontroluje, w jakim stopniu jednostka uwzględnia standardy norm funkcjonowania określających ludzką egzystencję. Jest najgłębszą, konstytutywną warstwą psychiki człowieka, w której zawarty jest niejako układ odniesienia dobra i zła. Sumienie stanowi prawo moralne istniejące w człowieku. Standardy ludzkiej egzystencji mogą znajdować swoje zastosowanie wtedy, gdy człowiek aktywnie uczestniczy w budowaniu swojej osobowości oraz wówczas, gdy człowiek wchodzi $\mathrm{w}$ interakcje $\mathrm{z}$ innymi osobami, ze światem widzialnym i światem nieobjętym zmysłowym poznaniem ${ }^{31}$.

\footnotetext{
${ }^{29}$ G. Allport, dz. cyt., s. 16-24.

${ }^{30}$ S. Szumna, Natura, osobowość i charakter człowieka, Kraków 1995, s. 186-196.

${ }^{31}$ D. Buksik, Wrażliwość sumienia. Studium psychologiczne, Warszawa 2003, s. 36-65.
} 
Te trzy scharakteryzowane elementy stają się podstawą do poszukiwania poziomu życia religijnego młodego człowieka przebywającego w ośrodku wychowawczym oraz wyznaczają szeroko pojętą dojrzałość osobowościową.

Głównym celem prezentowanych w artykule badań jest ukazanie poziomu życia religijnego młodego człowieka, który zostaje poddany procesowi wychowawczemu i w jakimś stopniu resocjalizacji w wyznaczonym do tego ośrodku wychowawczym. Przypuszcza się, że poznanie poziomu życia religijnego może pomóc wychowawcom ośrodka w procesie kształtowania osobowości młodego człowieka. Pytanie badawcze postawione w tym artykule dotyczy tego: czy poczucie winy, pozytywne postawy religijne oraz wrażliwość sumienia, jeśli są w młodym człowieku ważne i istotne dla niego, mogą stać się odniesieniem w procesie wychowawczym? Czy młody człowiek w oparciu o swoją religijność i moralność może wrócić do norm społecznego funkcjonowania? Autor opracowania jest przekonany, że odniesienie się do religii i moralnych zasad w postępowaniu, pewnej wrażliwości na nie, może stać się pomocne w procesie resocjalizacji.

\section{Metoda badań}

\subsection{Badane osoby}

Grupa eksperymentalna obejmowała młodzież z Salezjańskiego Ośrodka Wychowawczego w Trzcińcu. Oficjalnie dom nosi nazwę: „Domu Młodzieży im. św. Jana Bosko". Przebywają w nim głównie chłopcy, którzy zostali skierowani do ośrodka orzeczeniem sądowym. Są to osoby, które zgodnie ze współczesnym prawodawstwem za wchodzenie w konflikt z prawem, ucieczki z domu, czy też niezrealizowanie obowiązku szkolnego, umieszczane są w placówkach szkolnowychowawczych o charakterze resocjalizacyjnym. Czas przebywania chłopców w Ośrodku mieści się w przedziale od roku do trzech lat. Czasami czas ten jest dłuższy. Chłopcy trafili do ośrodka z różnorodnych powodów. Są to między innymi: kradzieże, włamania, wagary, ucieczki z lekcji, picie alkoholu, nierozliczenie obowiązku szkolnego, agresja wobec rówieśników, trudności wychowawcze, posiadanie i dystrybucja narkotyków, a w związku z tym sprawy sądowe, w wielu wypadkach demoralizacja. Grupa składała się z osób w przedziale wiekowym od 16 do 21 lat. Większość chłopców nie miała skończonej szkoły średniej i podstawowej. W momencie badania w Ośrodku znajdowało się 64 chłopców, z czego 4 nie zdecydowało się na pisanie testów.

Badaniem objęto 60 chłopców. Każdy z nich został objęty badaniem w zakresie następujących narządzi badawczych: Kwestionariusza Poczucia Winy (PW), Skali Postaw Religijnych W. Prężyny (SR) oraz Skali Wrażliwości Sumienia D. Buksika (SWS). Należy podkreślić, że badanie to odbyło się w sposób indywidu- 
alny, a nie grupowy. Każdy wychowanek indywidualnie w obecności psychologa odpowiadał na wszystkie pytania zawarte w trzech narzędziach. Jeśli zachodziła konieczność wytłumaczenia pytania, które nie było zrozumiałe, psycholog wyjaśniał je tak długo, aż chłopcy je rozumieli. Należy zaznaczyć, że wiele pytań było dla chłopców niezrozumiałych, może dlatego też nie wszystkie kwestionariusze nadawały się do statystycznej obróbki. Okazało się, że na 60 badanych można było wykorzystać tylko w Kwestionariuszu Poczucia Winy - 57 kwestionariuszy, w Skali Postaw Religijnych - tylko 40 kwestionariuszy, w Skali Wrażliwości Sumienia zaś - 51 kwestionariuszy. Natomiast do ukazania związków pomiędzy poszczególnymi skalami wykorzystano jedynie 40 kwestionariuszy tylko tych chłopców, którzy wypełnili wszystkie.

\subsection{Zastosowane metody badawcze}

W niniejszym opracowaniu do zbadania poziomu życia religijnego wykorzystano trzy narzędzia badawcze, które szeroko opisane są w literaturze przedmiotu. Tutaj dokonam tylko krótkiego przypomnienia, czym się charakteryzują wybrane narzędzia badawcze.

\subsubsection{Kwestionariusz Poczucia Winy (PW)}

Narzędzie zostało skonstruowane i psychometrycznie opracowane przez M. Koftę, J. Brzezińskiego i M. Ignaczaka ${ }^{32}$. Służy do badania tego elementu (aspektu) „mechanizmu osobowości, który decyduje o częstości pojawienia się, natężeniu i czasie zalegania poczucia winy jako przejściowego stanu podmiotu". Poczucie winy uważa się za czynnik odpowiedzialny za moralne zachowanie człowieka, za ukształtowaną zdolność do samokarania. Autorzy kwestionariusza przyjęli założenie, że poczucie winy stanowi ważny składnik mechanizmu samokontroli człowieka, który „decyduje o zdolności jednostki do modulowania i tłumienia własnych impulsów, odraczania w czasie ich gratyfikacji oraz dostosowania form ich zachowania do wymogów społecznych". Zdaniem autorów kwestionariusza, poczucie winy rozumiane jako wymiar osobowości powinno przejawić się nie tylko w zachowaniach związanych z przekroczeniem norm, ale również w postawach wobec innych ludzi, uogólnionych sądach o świecie i instytucjach społecznych. Autorzy ci przyjęli założenie, że poczucie winy bezpośrednio wpływa na stopień rygoryzmu sądów, opinii i ocen moralnych.

${ }^{32}$ M. Kofta, J. Brzeziński, M. Ignaczak, Konstrukcja i charakterystyka psychometryczna. Kwestionariusza Poczucia Winy (KPW), „Studia Psychologiczne” 16 (1977), s. 93-113. 


\subsubsection{Skala Postaw Religijnych W. Prężyny (SR)}

Postawę religijną autor określa jako „względnie trwałe ustosunkowanie się, które wyraża gotowość podmiotu do pozytywnych lub negatywnych reakcji (intelektualnych, emocjonalnych i behawioralnych) wobec określonego przedmiotu"33. Skala postaw religijnych zawiera 30 twierdzeń. Część z nich jest sformułowanych pozytywnie (np. Jezus Chrystus jest Synem Bożym), część zaś jest sformułowana negatywnie (np. Bóg jest fikcja). Twierdzenia rozłożono na siedmiostopniowym kontinuum. Przyjęto jako wzorzec skalę Likerta. Ogólny wynik pomiaru to suma punktów uzyskanych przez osobę badaną albo średnia wartość odpowiedzi dla wszystkich twierdzeń skali. Wynik niski będzie oznaczać wysoki stopień intensywności nieprzychylnej postawie religijnej, wynik zaś wysoki oznacza wysoki stopień intensywności przychylnej postawie religijnej. Na brak postawy religijnej lub niską jej intensywność wskazywać będą wyniki środkowe ${ }^{34}$.

\subsubsection{Skala Wrażliwości Sumienia (SWS)}

Skala Wrażliwości Sumienia opracowana została przez D. Buksika ${ }^{35}$. W skład Skali wchodzi 35 twierdzeń z czego 15 twierdzeń bada wrażliwość na siebie i innych (WSI), a 16 twierdzeń, bada wrażliwość na świat i wartości moralne (WŚWM), 4 twierdzenia stanowią pytania buforowe. W skład wrażliwości na siebie i innych (WSI) wchodzą twierdzenia dotyczące wrażliwości na głos sumienia, systematyczność, obowiązek i powinności, szacunek do samego siebie wypływający z akceptacji siebie takim, jakim się jest, samoakceptacja, samorealizacja, wrażliwość na cierpienie, umiejętność wybaczania jako pomoc w utrzymaniu dobrych relacji z drugim człowiekiem, uczestniczenie w akcjach dobroczynnych na rzecz osób biednych, chorych i opuszczonych. Natomiast w skład wrażliwości na świat i wartości moralne (WŚWM) wchodzą twierdzenia dotyczące odpowiedzialności za otaczający świat, czystość środowiska, zdobywanie wiedzy o otaczającym świecie, wrażliwość na cierpienie ludzi na innych kontynentach, wrażliwość na takie wartości, jak: samobójstwo, eutanazja, poszanowanie życia, prawda, posiadanie hierarchii wartości oraz wrażliwość na prawa wynikające z Dekalogu.

\footnotetext{
${ }^{33}$ W. Prężyna, Skala, s. 77.

${ }^{34}$ Tenże, Potrzeby, s. 5-28; tenże, Funkcja, s. 20-34.

${ }^{35}$ D. Buksik, dz. cyt., s. 36-65.
} 


\subsection{Wyniki badań i dyskusja}

W badaniu przyjęto, że poziom życia religijnego będzie wyznaczał wysoki wynik w Skali Intensywności Postaw Religijnych (SR), wysoki wynik w Kwestionariuszu Poczucia Winy (KPW) oraz wysoki wynik w Skali Wrażliwości Sumienia (SWS). Wyniki ogólne w poszczególnych skalach pokazały, że młodzież charakteryzuje niższa wrażliwość sumienia zarówno w relacji do siebie, innych (m.in. na takie wartości, jak wrażliwość na cierpienie, wrażliwość na głos sumienia, umiejętność wybaczania, utrzymanie dobrych relacji z innymi), jak i do otaczającego świata i wartości ogólnoludzkich, tj. wrażliwość na cierpienie innych, dbanie o czystość środowiska, wrażliwość na poszanowanie życia, wrażliwość na prawdę i prawa wynikające z Dekalogu (zob. tabela 1). Równocześnie młodzież odznacza się niską intensywnością postaw religijnych oraz niskim poczuciem winy (zob. tabele 2 i 3).

Badania poziomu wrażliwości sumienia przeprowadzono za pomocą skali Wrażliwości Sumienia (SWS). Dane statystyczne dotyczące wyników badań za pomocą Skali Wrażliwości Sumienia, charakterystyczne dla grupy, prezentuje tabela 2 . W tabeli są umieszczone średnie, mediany, odchylenie standardowe z wyników pomiaru wrażliwości sumienia dla całej grupy.

Tabela 1. Średnie, mediany, odchylenie standardowe z wyników pomiaru wrażliwości sumienia dla całej grupy

\begin{tabular}{|l|c|cccc|}
\hline \multirow{2}{*}{ Zmienne } & \multicolumn{5}{c|}{ Cala grupa (N=51) } \\
\cline { 2 - 6 } & średnia & mediana & maksimum & minimum & $\mathrm{s}$ \\
\hline WO & 156,0784 & 150 & 230 & 90 & 28,50392 \\
\hline WSI & 69,0980 & 68 & 105 & 40 & 13,66346 \\
\hline WSW & 86,0784 & 82 & 125 & 50 & 19,14768 \\
\hline
\end{tabular}

Objaśnienia:

s - odchylenie standardowe; WO - Wynik ogólny w Skali Wrażliwości Sumienia; WSI - Wrażliwość na Siebie i Innych;

WŚWM - Wrażliwość na Świat i Wartości Moralne

Średni wynik dla całej przebadanej grupy (51 osób) w poziomie wrażliwości sumienia - WO wynosi (= 156,07 $\mathrm{s}=28,50)$; dla poszczególnych skal jest następujący: dla skali wrażliwości na siebie i innych - WSI wynosi $(=69,09$ $\mathrm{s}=13,66$ ), a dla skali wrażliwości na świat i wartości moralne - WŚWM wynosi $(=86,07 \mathrm{~s}=19,14)$.

Analiza postawy religijnej została przeprowadzona na podstawie wyników badań Skalą Postaw Religijnych (SR). Dane zawarte w skali do badania postawy religijnej dla grupy zamieszczone są w tabeli 3. Tabela ta prezentuje średnie, mediany, odchylenie standardowe z wyników pomiaru postaw religijnych. Średni wynik w kwestionariuszu dla całej przebadanej grupy wynosi: $=125,0$ $\mathrm{s}=42,14$. 
Tabela 2. Średnie, mediany, odchylenie standardowe z wyników postaw religijnych mierzonych skalą Postaw Religijnych (SR) dla całej grupy

\begin{tabular}{|l|ccccc|}
\hline \multirow{2}{*}{ Zmienne } & \multicolumn{5}{c|}{ Cala grupa (N=40) } \\
\cline { 2 - 6 } & średnia & mediana & maksimum & minimum & $\mathrm{s}$ \\
\hline SR & 125,375 & 126,5 & 194 & 40 & 42,14668 \\
\hline
\end{tabular}

Objaśnienia:

s-odchylenie standardowe; SR - Skala Religijności

Natomiast analizy poczucia winy dokonano na podstawie wyników badań Kwestionariuszem Poczucia Winy (KPW). Dane empiryczne zawarte w kwestionariuszu do badania poczucia winy, charakterystyczne dla grupy, zamieszczono w tabeli 3. Tabela zawiera średnie, mediany, odchylanie standardowe z wyników pomiaru poczucia winy dla całek grupy. Średni wynik w kwestionariuszu dla całej przebadanej grupy wynosi: $=125,0 \mathrm{~s}=42,14$.

Tabela 3. Średnie, mediany, odchylenie standardowe z wyników pomiaru poczucia winy mierzonego kwestionariuszem do badania Poczucia Winy (KPW) dla całej grupy

\begin{tabular}{|l|c|c|c|c|c|}
\hline \multirow{2}{*}{ Zmienne } & \multicolumn{5}{c|}{ Cala Grupa (N=57) } \\
\cline { 2 - 6 } & średnia & mediana & maksimum & minimum & s \\
\hline SR & 19,35088 & 20 & 30 & 0 & 8,333434 \\
\hline
\end{tabular}

Objaśnienia:

s - odchylenie standardowe; KPW - Kwestionariusz Poczucia Winy

Dla pełniejszego zobrazowania poziomu życia religijnego osób przebywających w Ośrodku Wychowawczym dokonano statystycznego uchwycenia wzajemnych zależności pomiędzy poszczególnymi wymiarami, jakimi są wrażliwość sumienia, postawa religijna i poczucie winy. Wszystkie korelacje ukazują tabele: 4,5 i 6 .

Tabela 4. Korelacje (r-Pearsona) wyników skali Wrażliwości Sumienia ze skalą Postaw Religijnych

\begin{tabular}{|l|c|}
\multicolumn{1}{|c|}{ Zmienne } & Skala Postaw Religijnych \\
\cline { 1 - 1 } WO & Cała grupa \\
& $\mathrm{r}=0,2266$ \\
$\mathrm{y}$ WSI & $\mathrm{p}=0,160$ \\
& $\mathrm{r}=0,099$ \\
$\mathrm{y}$ WSWM & $\mathrm{P}=0,542$ \\
& $\mathrm{r}=0,190$ \\
$\mathrm{y}$ & $\mathrm{p}=0,240$ \\
\hline
\end{tabular}

Objaśnienia:

p-poziom istotności różnicy; r - wynik korelacji r-Pearsona; WO - Wynik ogólny w Skali Wrażliwości Sumienia; WSI - Wrażliwość na Siebie i Innych; WŚWM - Wrażliwość na Świat i Wartości Moralne 
Tabela 5. Korelacje (r-Pearsona) wyników Skali Wrażliwości Sumienia z Kwestionariuszem Poczucia Winy

\begin{tabular}{|l|c|}
\hline \multicolumn{1}{|c|}{ Zmienne } & Kwestionariusz Poczucia Winy \\
\cline { 1 - 1 } WO & Cała grupa \\
& $\mathrm{r}=0,214$ \\
$\mathrm{y}$ WSI & $\mathrm{p}=0,183$ \\
& $\mathrm{r}=0,058$ \\
$\mathrm{y}$ WSWM & $\mathrm{P}=0,721$ \\
& $\mathrm{r}=0,346$ \\
$\mathrm{y}$ & $\mathrm{p}=0,029$ \\
\hline
\end{tabular}

Objaśnienia:

p-poziom istotności różnicy; $\mathrm{r}$ - wynik korelacji r-Pearsona; WO - Wynik ogólny w Skali Wrażliwości Sumienia; WSI - Wrażliwość na Siebie i Innych; WŚWM - Wrażliwość na Świat i Wartości Moralne

Tabela 6. Korelacje (r-Pearsona) wyników skali Postaw Religijnych z Kwestionariuszem Poczucia Winy

\begin{tabular}{|l|c|}
\hline Zmienne & Skala Postaw Religijnych \\
\hline \multirow{3}{*}{ KPW } & Cała grupa \\
& $\mathrm{r}=0,150$ \\
$\mathrm{p}=0,355$ \\
\hline
\end{tabular}

Objaśnienia:

$\mathrm{p}$ - poziom istotności różnicy; $\mathrm{r}$ - wynik korelacji r-Pearsona; KPW - Kwestionariusz Poczucia Winy

Skoro osoby badane odznaczają się niskimi wynikami w poszczególnych wymiarach, to spróbowano zobaczyć, jakie związki zachodzą pomiędzy poszczególnymi wymiarami i czy w ogóle takie związki zachodzą. Wewnętrznym przekonaniem badacza było, że osoby odznaczające się niską wrażliwością sumienia będą również posiadały słabe postawy religijne oraz będą odznaczały się barkiem poczucia winy. Istotny dla całości badania poziomu rozwoju życia religijnego jest fakt, że w grupie badanej nie ma żadnych istotnych korelacji pomiędzy poszczególnymi wymiarami. Może to wskazywać na rzeczywiście niski poziom życia religijnego lub też na typowe zachowania antyspołeczne, w których brak wyraźnej motywacji, brak poczucia winy, brak wstydu i odpowiedzialności czy też ubóstwo emocjonalne i brak lęku. Krótko mówiąc, brak integracji sfery poznawczej, emocjonalnej, motywacyjnej, religijnej, duchowej i moralnej. Oczywiście, postawienie wniosku, że są to osobowości dyssocjalne byłoby chyba dużym uproszeniem. Dlatego, że gdybyśmy indywidualnie rozpatrzyli poszczególne osoby, to okazuje się, że poziom życia religijnego wygląda inaczej. Okazuje się, że osoby z wrażliwością sumienia odznaczają się też wysokim stopniem intensywności postawy religijnej, czy też poczuciem winy. 


\section{Wnioski}

Rzeczywistość religijna z racji swej złożoności może być opisywana i interpretowana interdyscyplinarnie, z punktu widzenia teologicznego, socjologicznego, etycznego, psychologicznego czy pedagogicznego. W niniejszym opracowaniu wykorzystano wiedzę psychologiczna, zarówno w jej wymiarze teoretycznym, jak i zastosowanych metod badawczych. Badania pokazały, że religijność jest wpisana w strukturę osobowości człowieka. Chociaż czasami jest ona niepogłębiona lub też zaniedbana, to jednak odgrywa istotną rolę w życiu młodego człowieka, przynajmniej w wymiarze indywidualnych odniesień.

Z całą pewnością możemy stwierdzić, że w wypadku osób przebywających w Ośrodku ich poziom życia religijnego jest niski, niedostateczny i gdzieś w ciagu ich życia zaniedbany. Dlatego też konieczne jest nie tylko dalsze jego kształtowanie, ale również pogłębianie, by zdobyta wiedza religijna pozwalała na dokonywanie świadomych i lepszych wyborów. Kształtowanie postawy religijnej może pobudzić młodego człowieka do zmiany dotychczasowego postępowania, głębokiej refleksji nad swoim życiem, czy też odnalezienia w relacji osobowej do Boga wewnętrznego spokoju i zadowolenia z życia. Prawidłowe wychowywanie do kształtowania swojego sumienia, a w tym jego wrażliwości, powinno skutkować poszanowaniem drugiego człowieka, otaczającego świata i dokonywaniem wyborów zgodnych z systemem wartości opartym na Dekalogu. Należy również rozwijać w młodym człowieku poczucie winy, nie jako lęku przed karą, ale jako świadomego i wolnego wyboru dobra oraz możliwości budowania osobowości wolnej od obciążeń przeszłością.

\section{The level of the development of religiousness in the young staying at juvenile detention centres} (Summary)

Religious development is a long-lasting and gradual process. Being, at the same time, determined by a variety of factors originating from both conditions of outer nature such as upbringing and certain inner circumstances like personal experience it is also a very burdensome one. An important moment in the development of religiousness is when a man becomes mature and independent due to establishing one's own views. Many authorities point that a well-developed religiousness should be reflected on in the process of upbringing, prevention and rehabilitation of certain kind. Previous experience of religiousness might begin the process of changing the awareness of people undergoing rehabilitation. The main aim of this work is to show and analyse the level of religiousness of a young man undergoing the process of upbringing and rehabilitation at a juvenile detention centre. On such a basis conclusions of educational nature which should foster the development of mature personality with reference to certain spheres of religiousness shall also be drawn in this work. 